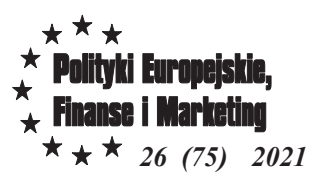

DOI $10.22630 /$ PEFIM.2021.26.75.12

Received: 16.07 .2021

Accepted: 20.11.2021

Zenon Pokojski

Maria Curie Sklodowska University, Lublin

\title{
PARTNERSHIP IN OPEN INNOVATIONS - EXPERIENCE FROM THE AGRICULTURAL MARKET: POLAND CASE STUDY
}

The ability to build and manage a knowledge transfer partnership is one of the most highly demanded skills. Knowledge is widely dispersed, so it should be acquired from the environment. For this purpose, partnerships should be established with different entities. Presumably, the most mature type of partnership is the innovation ecosystem. Hence empirical research was conducted among Poland's Grupa Azoty (GA) Puławy's consortium members based on an in-depth, partially structured interview, supported by an analysis of several innovation ecosystems of chemical companies. The aim of the research was to assess the phenomenon of open innovations in the GA along with the characteristics of the selection of partners, cooperation strategies and declared resources for jointly implemented projects.

Keywords: partnership, open innovation, innovation ecosystem, innovation management, knowledge transfer.

JEL Codes: O320, M21

\section{Introduction}

In conditions of turbulent changes in the business environment, seeking innovation requires the cooperation of various partners, including those from the public sector and non-governmental organizations. Therefore, some kind of partnership is necessary to cocreate value. Partners share their knowledge and experience as well as the benefits of jointly conducted innovative projects. The company uses external knowledge, but also shares some of its ideas and solutions. Innovations are created on the basis of coproduction. Partnerships are established to implement individual stages as well as the entire innovation process. The selection of participants can be focused on specific partners or to multiple entities interested in solving a defined problem, and even to entire communities of users or customers. The most important stakeholders are:

- cooperation with partners along the supply chain,

- cooperation with buyers/customers,

- cooperation with competitors,

- cooperation with scientific partners,

- cooperation with partners from the public sector,

- cooperation with partners from multiple sectors.

Obviously, cooperation may also involve partners jointly interested in the same market segment, e.g. the agri-food segment. 
Partnership cooperation may be carried out on the basis of various organizational and legal structures. The most popular are the consortium and the strategic alliance. The concept of a consortium does not have its official definition in the Polish legislative acquis, therefore, it is very difficult to clearly define its constitutive features. According to the definition adopted in the literature, this concept is used to describe two or more entrepreneurs jointly pursuing a certain economic goal. The difference between a consortium and a strategic alliance lies primarily in the temporary nature of the consortium, as opposed to a strategic alliance which usually takes the form of long-term cooperation. It is worth noting that a consortium may sometimes take the form of a strategic alliance.

In collaborative innovation partnerships, especially with undefined user/customer communities, project participants share their intellectual capital as well as, to a certain extent, the effects of cooperation. The flow of knowledge between an organization and its external environment is bilateral. Collaboration with communities is often informal and involves great problems in managing such projects. Such partnerships require development of open innovation platforms on the Internet:

- crowdsourcing (using the crowd as a source of knowledge, its wisdom) ${ }^{5}$,

- co-production or coopetition (common participation, cooperation of people or companies in search of innovation, even companies competing with each other) ${ }^{6}$,

- open source software ${ }^{7}$.

Crowdsourcing is sponsored by an organization that directly manages the "crowd" to achieve its goals. Crowdsourcing platforms act as intermediaries in multilateral markets and as such are at the core of the knowledge sharing and intellectual property transfer process between multiple actors.

Activity based on co-production, which means universal participation and cooperation in production, refers to a new production model based on the cooperation of a large number of entities in the implementation of projects outside the hierarchical, traditional structures of the organization. Coopetition means cooperation between competitors in areas where it is necessary, without ceasing to compete with each other. Today, companies are engaging in strategic partnerships that have both collaborative and competitive elements. These partnerships can be created, changed and terminated depending on the evolution of the market environment, even in very short periods of time ${ }^{8}$.

\footnotetext{
${ }^{5}$ V. Chanal \& M.L. Caron-Fasan: The difficulties involved in developing business models open to innovation communities: the case of a crowdsourcing platform. Management, 2010, 13: 318-340. Available at https://doi.org/10.3917/mana.134.0318 (accessed Jan 2021).

${ }^{6}$ R. Gulati, N. Nohria \& A. Zahher: Strategic networks. Strategic Management Journal, 2000, 21 (3): 203-215. Available at https://doi.org/10.1002/(SICI)1097-0266(200003)21:3<203::AID-SMJ102>3.0.CO;2-K (accessed Jan 2021).

${ }^{7}$ K.R. Lakhani, E., von Hippel: How open source software works:"free" user-to-user assistance. [in]: Produktentwicklung mit virtuellen Communities. Gabler Verlag, 2004. Available at https://dspace.mit.edu/bitstream/handle/1721.1/70028/von Hippel (accessed Jan 2021).

${ }^{8}$ R. Gulati at al., 2000, op. cit.
} 
The platform with the broadest, most open formula of participation is open source ${ }^{9}$ Increasingly, open source is perceived more as a concept on which many companies base their innovative activities, rather than a kind of technological process. Open source software enables companies to acquire, often free of charge, new solutions for their ideas or processes. Until recently, business viewed the open source movement more as a threat, but with the success of the Linux project, that perception has changed. Today, many companies see open source as an opportunity to create new competitive advantages.

Recently, the concept of the innovation ecosystem has been gaining more and more popularity in the literature on the subject. Innovation ecosystems are forms of cooperation in which companies integrate their individual offer proposals into homogeneous solutions with significant value for the client ${ }^{10}$. It can be said that the innovation ecosystem is the most advanced form of partnership. Authors define this ecosystem as a business ecosystem that aims to create and capture value from innovative activities (related to technological or business innovations) ${ }^{11}$. The authors note that value creation refers to collaborative processes and activities to create value for customers and other stakeholders, while value identification or capture (some use the term "appropriation") refers to individual, enterprise-level profit, meaning that companies strive to achieve their own competitive advantages and profit therefrom. ${ }^{12}$

Managing partnerships, networks or, more broadly speaking, ecosystems is nowadays considered a key competence of an organization ${ }^{13}$. Therefore, scientists and business practitioners are interested in searching for ways to build and manage such structures both in the business and innovative dimensions ${ }^{14}$.Usually cooperating entities implement innovative projects based on IT tools on the initiative and under the leadership of a leader ${ }^{15}$. The ecosystem should also be viewed from the perspective of a developing community that uses the resources of cooperating partners to implement its

${ }^{9}$ K.R. Lakhani \& E. von Hippel, 2004, op. cit.

${ }^{10}$ D.J. Jackson: What is an innovation ecosystem? Arlington, National Science Foundation, 2011. Available at https://www.researchgate.net/profile/Deborah-Jackson-7/publication/266414637 (accessed Jan 2021); H. Chesbrough, S. Kim, \& A. Agogino: Chez Panisse: Building an open innovation ecosystem. California Management Review, 2014, 56 (4): pp. 144-177. Available at https://doi.org/10.1525/cmr.2014.56.4.144 (accessed Jan 2021).

${ }^{11}$ P. Ritala, L. Armila, K. Blomqvist, K: Innovation orchestration capability - defining the organizational and individual level determinants. International Journal of Innovation Management, 2009, 13 (4): 569-591. Available at https://doi.org/10.1142/S136391960900242X (accessed Jan 2021).

12 J.A. Adegbesani \& M.J. Higgins: The intra-alliance division of value created through collaboration. Strategic Management Journal, 2010, 32: pp. 187-211. Available at https://doi.org/10.1002/smj.872 (accessed Jan 2021.

${ }^{13} \mathrm{~K}$. Blomqvist, \& J. Levy: Collaboration capability - a focal concept in knowledge creation and collaborative innovation in networks. International Journal of Management Concept and Philosophy, 2006, 2 (1), pp. 31-48. Available at https:/www.researchgate.net/profile/Kirsimarja-Blomqvist/publication/ (accessed Jan 2021); P. Ritala, L. Armila \& K. Blomqvist: Innovation orchestration capability - defining the organizational and individual level determinants. International Journal of Innovation Management, 2009, 13 (4): pp. 569-591. Available at https://doi.org/10.1142/S136391960900242X (accessed Jan 2021).

${ }^{14}$ R. Adner: Match your innovation strategy to your innovation ecosystem, Harvard Business Review, 2006, 84 (4), pp. 98-107. Available at www.hbrreprints.org. (accassed Jan 2021);

${ }^{15}$ D.J. Teece: Explicating dynamic capabilities: the nature and microfoundations of (sustainable) enterprise performance, Strategic Management Journal, 2007, 28(13), 1319-1350. Available at doi: https://doi.org/10.1002/smj.640 (accessed Jan 2021). 
innovative projects ${ }^{16}$. The ecosystem also has a social dimension and offers the potential not only to create and share economic but also social value. In the process of creating value for society and business, five elements are important - social goal, defined need, value measures, appropriate structure for an innovation project and co-creation. Thanks to the application of a model composed of these elements, by creating common value many corporations achieve their basic business goals - value for investors/shareholders. Authors provide many examples of projects carried out by Dow Chemicals, Nestlé, Novartis, Mars, Intel, Becton Dickinson and Vodafone, which have achieved social and economic success with their innovation systems ${ }^{17}$.

\section{Material and methods}

\section{Innovative activity of selected companies in the chemical sector}

In order to examine the functioning of the innovation ecosystem, the analysis covered international corporations that are leaders in the chemical industry in the area of agricultural products with a business profile similar to that of Grupa Azoty Puławy: BASF, MONSANTO, SOLVAY and YARA, as well as structures such as: The Fertilizers Institute in the United States, UNIFA - Association of French fertilizer manufacturers, CropLife, Axelera (Solvay).

The analysis was used not only to study the organization of research and development processes but also to prepare the concept of an organization model that is open to innovation. In the broadly understood openness of chemical companies to building open innovation ecosystems, it was possible to distinguish five areas of innovative activity or support in building the value of the organization: research and development activity, activity within the open innovation formula, consulting and education, public relations, lobbying and think tanks. The author analysed chemical companies in the context of these areas and the understanding of their expert functions.

All analysed companies put a lot of effort into research and development activities, not limited to their own departments, but developing it "beyond the borders" of their companies. They are also not limited to searching for and implementing new, innovative products or technologies, but they develop their activities based on new organizational and marketing solutions aimed at building value for their customers. A frequently quoted argument is the proposal to jointly search with other stakeholders for solutions to global challenges. To this end, they try to build open innovation ecosystems, including education, Think tanks (expert functions), and advocacy of interests.

In research and development projects in the field of agriculture, the most popular trend in conducting research and development is going beyond own organizational structures and laboratories. They are very willing to engage in joint projects with other stakeholders by appointing new specialized entities to coordinate these activities. Prospective innovations are developed on the basis of Special Purpose Vehicles (SPVs),

${ }^{16}$ E. Autio \& L. Thomas: Innovation ecosystems: Implications for innovation management. In M. Dodgson, D. M Gann,. \& N. Phillips, Innovation management: Oxford University Press, 2014, 204-288.

${ }^{17}$ M.W. Pfitzer, V. Bockstette \& M. Stamp: Innovating for shared value, Harvard Business Review, 2013, 86: 100-107. 
mainly to minimize investment risk $^{18}$. New investments most often take the form of start-up, spin-off or joint ventures.

New entities in the innovation ecosystem of chemical companies are looking for additional sources of financial support based on public funds intended for the stakeholders of the agri-food sector; they need to use venture capital or fundraising tools. In this way, they expand the possibilities of commercializing innovations, increasing the potential of the market. They develop new mechanisms for building and managing the ecosystem. Intellectual property becomes a strategic asset in building the company's value.

Another noticeable trend is investing in the biotechnology and nanotechnology sectors in search of solutions to meet difficult challenges, such as food and drinking water shortages, and food insecurity with a constantly growing population of inhabitants. It is unpopular to run $\mathrm{R} \& \mathrm{D}$ projects focused on only one branch of industry. The analysed companies, together with universities and institutes, try to open up to innovations in other sectors of the economy in search of solutions, ideas and ideas for building value. The African continent is of particular interest.

An important area of interest of the analysed companies is activity in the form of think-tanks. The communication of the chemical company with the environment is of limited effectiveness, while the message provided by independent experts is more credible. Hence, the above-mentioned entities are willing to organize or support thinktanks to make their actions more credible in the eyes of public opinion, as well as decision-makers. The following activities of think-tanks are the most popular:

- Creating online platforms for specialists, scientists, hobbyists and enthusiasts in order to create the opportunity to discuss global challenges of humankind,

- Promoting membership in organizations working for environmental protection, sustainable development, climate change dilemmas, food security, circular economy, etc.,

- Preparing reports, expressing opinions and positions by authorities invited to cooperate.

A popular activity of the analysed companies is to group into non-profit organizations in order to adequately represent their interests, on the one hand, and to promote solutions that improve the image of their business on the other hand. They eagerly create rules, norms and canons for self-regulation of behaviour in order to ensure proper regulations, often in response to public criticism or ahead of the actions of regulators. An example of such an activity is a Product Stewardship project. Chemical companies actively participate in lobbying activities. Some talk about it directly by

\footnotetext{
${ }^{18}$ The name of the special purpose vehicle SPV (Special Purpose Vehicle) appeared in the 1990's together with the so-called political transformation in Poland. Initially, the SPV operated as a joint venture and limited the investment risk by the partners of the special purpose vehicle, also known as project sponsors. K. Czerkas, Special purpose vehicle: creation, application, functioning, financing, ODDK, Gdańsk 2017, p. 32. Currently, a special purpose vehicle (SPV) is a company established to achieve specific goals set by its partners, i.e. project sponsors. Typically, the parent company decides to form a subsidiary that serves the specific economic purpose of the parent company. This solution allows the parent company to reduce the risk associated with participation in a new project. A. Roguska-Kikoła, D. Rutkowska, H. Dessoulavy-Śliwińska, SPV and a consortium, Difin, Warsaw 2016, p. 39; G.B. Gorton, \& N.S.Souleles, 2007.
} 
creating special cells in their structures, others point to the activities of advocacy groups, which in fact boils down to exerting influence on decision-making processes and centres.

Summarizing the analysis of selected chemical companies, it should be noted that all of them build wider structures, based on partnerships with other business entities, and more and more willingly with public sector entities, non-governmental organizations, individual users or Internet communities. The analyzed chemical companies, developing their innovative activities, create innovation ecosystems. They open up to global cooperation in the implementation of research and development projects by sharing their know-how, while using the knowledge and skills of specialists from various industries, units and regions of the world.

Scientific literature is more and more willing to take up the subject of concepts and case studies of creating and managing such innovation ecosystems. However, there is a lack of research by leaders of innovation ecosystems on value creation as well as its capture in their ecosystem. Understanding the creation and capture of value in the ecosystem is the search for answers to the question of how markets are created and how different partners can pursue common and their own business goals.

\section{Empirical research on the consortium}

In October 2019, the authors conducted empirical research among the consortium members of Grupa Azoty Puławy according to an in-depth, partially structured interview scenario. Established in 2011, the consortium called Puławy Competence Center (Consortium) grouped 12 entities representing three types of entities: research centres, producers of agricultural products and their clients and organizations representing agricultural entrepreneurs. It was an attempt to open up the Group primarily to incoming innovations. It should be emphasized that the strategic goal of the Consortium was to build the foundations of an innovation ecosystem aimed at developing the value of end customers in the agri-food market segment. The initiators who established the Consortium wanted to increase Grupa Azoty Puławy's absorption capacity for innovation and thus increase the market value of the Group and its cooperating partners.

The analysis of this case is valuable because the practice of using open innovations on agricultural markets is extremely rare, therefore, we are dealing with an early stage of knowledge development in this area of research ${ }^{19}$. It should be added that the attempt to open up to innovation was unsuccessful, because since 2016 the above-mentioned Consortium, after changing the composition of the Group's management board, did not take any further activity. It could be said that the Group was not prepared to use open innovation, which was a source of dissatisfaction and abandonment of this formula of innovative activities ${ }^{20}$.

In total, 14 interviews were conducted, including seven with representatives of Polish science, four with business representatives (3 with members of the top

\footnotetext{
${ }^{19}$ Z. Pokojski: In searching for business model open for innovations on agricultural market - conceptual approach, Proceedings of the 2018 International Scientific Conference 'Economic Sciences for Agribusiness and Rural Economy' No 1, Warsaw, 7-8 June 2018, 237-242, Available at DOI: 10.22630/ESARE.2018.1.33.

${ }^{20} \mathrm{H}$. Chesbrough \& S. Brunswicker: The adoption of open innovation in large firms. Technology Management, 2018, 61: 35-45. Available at https://doi.org/10.1080/08956308.2018.1399022 (accessed Jan 2021).
} 
management and 1 with the head of the CK Puławy cell at GAP) and three with the chairmen of agricultural entrepreneurs' organizations.

Scientific literature is more and more willing to take up the subject of concepts and case studies of creating and managing innovation ecosystems ${ }^{21}$. However, there is a lack of research on innovation ecosystem leaders at the intra-organizational level of analysis.

\section{Results and discussion}

The first research problem is the partnership evaluation. Answers were sought to the question: which partners, according to the respondents, are the most important for the success of the projects and who is to decide on their selection. Respondents were asked to rate the importance of external partners on a scale of 1-5 (1 - negligible, 5 - very important) for the success of the projects. The results are shown in Figure 1.

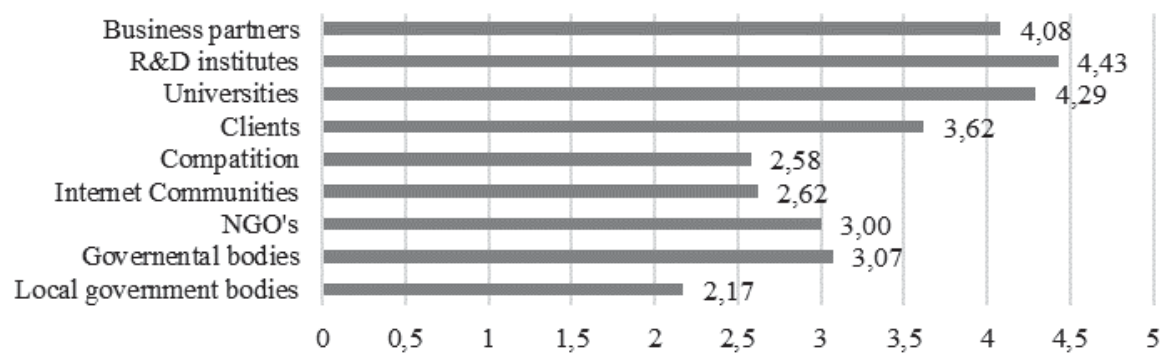

Figure 1. The significance of external partners for the success of projects carried out in the Consortium on a scale of 1 - 5

Source: Author's own study.

According to the respondents, the most "valuable" partners are research institutes (4.43), universities (4.29) and business partners (4.08), provided that they are not competitors. The least expected partners are local government organizations (2.17), competitors (2.58) and Internet communities (2.62). It is quite surprising that respondents underestimate online communities as a source of potential innovation.

It should be emphasised that Chesbrough and Brunswicker (2018) studies have shown that the most valuable element for partnerships is cooperation both at the stage of defining and solving the problem with clients, then with universities and research centres and other entrepreneurs (mainly suppliers). Competitors and different kinds of communities, just as with this case study, were the least preferred source of knowledge acquisition or project partner. Competitive companies and Internet communities were similarly viewed with reluctance, both in terms of participation in the creation of open innovations and the expected future cooperation in the authors' previous studies ${ }^{22}$.

${ }^{21}$ P. Ritala, P. Hurmelinna-Laukkanen \& S. Nätti: Coordination in innovation-generating business networks the case of Finnish mobile TV development. Journal of Business \& Industrial Marketing, 2012, 27 (4): 324 334. Available at . https://doi.org/10.1108/08858621211221698 (accessed Jan 2021).

${ }^{22}$ H. Chesbrough \& S. Brunswicker: Managing open innovation in large firms. Garwood Center for Corporate Innovation at California University, Berkeley in US \& Fraunhofer Society in Germany, 2013. Available at http://www.iot.ntnu.no/innovation/norsi-pims-courses/chesbrough/(accessed Jan 2021). 
Interesting observations concern the method of selecting partners for the Consortium. Four possibilities of selecting partners were indicated (Figure 2):

- open to any interested entity servicing the agri-food market;

- open, controlled by the Consortium leader;

- open, controlled according to the Consortium's indications;

- closed to additional partners.

The respondents are open to the selection of additional partners, but in a controlled or, in other words, selective manner, as indicated by the Consortium leader $(71.4 \%)$. This suggestion is not surprising, given that the leader is the initiator and sponsor of the project. None of the respondents was closed to additional partners.



Figure 2. Method of selecting partners for the Consortium

Source: Author's own study.

Ecosystem management requires the establishment of material mechanisms (contracts, regulations, intellectual property rights) and intangible cooperation (open communication, trust, organizational culture) ${ }^{23}$. Olander et al. refer to them as contractual and relational management mechanisms ${ }^{24}$. Laursen and Slater call openness 'soft' and 'hard' ${ }^{25}$. Both mechanisms are complementary and necessary in open innovation processes. For the research, the authors decided to divide the cooperation strategy into: conservative, limited trust, full of trust and innovative.

In CK Puławy's research, most responses (50.0\%) chose the strategy of limited trust, consisting in formalized cooperation with partners from outside the economic path (Figure 3). It was similarly attractive to representatives of science and business.

\footnotetext{
${ }^{23}$ Ø. Fjelstad, C. Snow, R. Miles \& C. Lettl: The architecture of collaboration, Strategic Management Journal, 2012, 33 (6), pp.734-750. Available at https://doi.org/10.1002/smj.1968 (accessed Jan 2021).

${ }^{24}$ H. Olander, P. Hurmelinna-Laukkanen, K. Blomqvist \& P. Ritala: The dynamics of relational and contractual governance mechanisms in knowledge sharing of collaborative R\&D projects, Knowledge and Process Management, 2010, 17 (4), pp. 188-204. Available at doi: https://doi.org/10.1002/kpm.356 (accessed Jan 2021).

${ }^{25}$ K. Laursen \& A. Salter: Open innovation: The Role of Openness in Explaining Innovation Performance Among U. K. Manufacturing Firms, Strategic Management Journal, 2006, 27. Available at doi: https://doi.org/10.1002/smj.507 (accessed Jan 2021).
} 


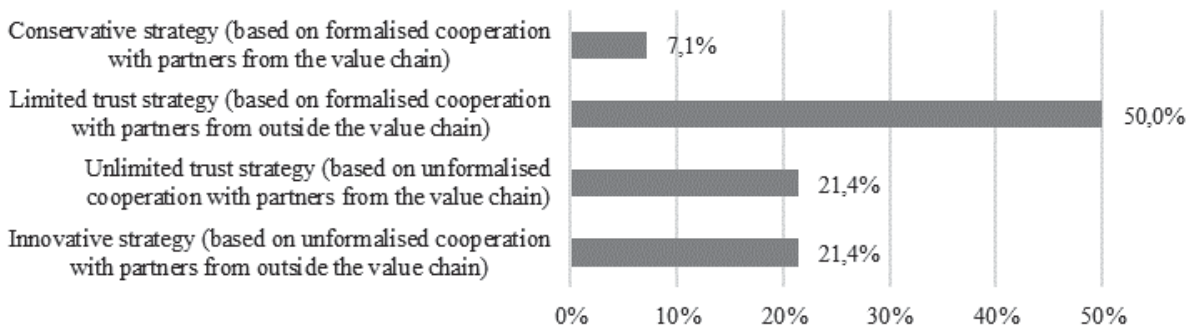

Figure 3. Cooperation strategy in the Consortium

Source: Author's own study.

The importance of formalizing cooperation for partners is notable. The innovative strategy was attractive only to representatives of science. Similarly, in the study by $\mathrm{Du}$, Leten and Vanhaverbeke (2014) representatives of science achieve better results in partnerships if they are managed "loosely" or less formally (loosely manager project) ${ }^{26}$. It is notable that the respondents indicated the cooperation of partners from outside the value chain, in line with the idea of establishing a Consortium. The partners were selected according to the criterion of interest in the same market segment. The strategy of formalized cooperation with partners from the economic path would be the least attractive in the opinion of the respondents.

The survey did not indicate a more favourable model of openness, according to the respondents. "Soft openness" and "hard openness" have the same number of supporters. A closer analysis of the results showed that the first type of openness was most often indicated by representatives of science and customers (agricultural entrepreneurs). On the other hand, all producers were supporters of "hard openness", which consisted in formalizing cooperation based on appropriate agreements (Figure 4).

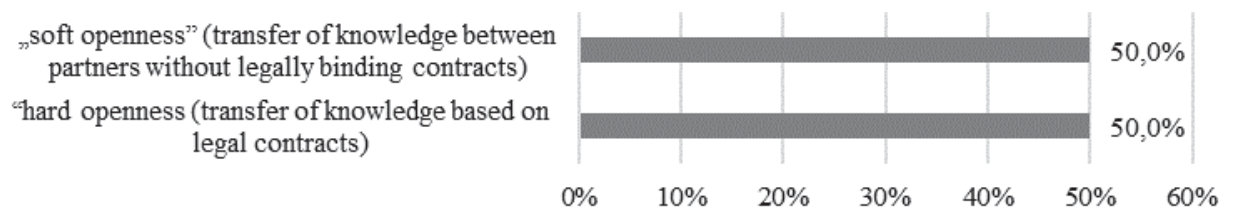

Figure 4. The model of openness in the transfer of knowledge between members of the Consortium Source: Author's own study.

Another research problem concerned the attempt to resolve the paradox dilemma related to the natural tension between sharing knowledge and protecting it. The dilemma boiled down to the choice of the openness model in the transfer of knowledge between partners. The respondents could choose between "soft openness", consisting in the transfer of knowledge between partners without legally formalizing this transfer, and "hard openness", understood as cooperation based on contracts and agreements.

${ }^{26}$ J. Du, B. Leten \& W. Vanhaverbeke: Managing open innovation projects with science-based and marketbased partners. Research Policy, 2014, 43(5), pp. 828-840. Available at https://doi.org/10.1016/j.respol. 2013.12.008 (accessed Jan 2021). 
Another research problem was to identify the interests of partners in research and development projects and in open innovation. The respondents were asked to indicate in their opinion the most important research areas that were of interest to its members in 2011-2016. The respondents could indicate a few most important aspects in their opinion (Figure 5).

The respondents pointed primarily to the issues of limitations in the access of plants to water and nutrients, as well as research and development projects concerning fertilizers with slow release of ingredients, blending, etc. (78.6\% of indications). Sustainable agriculture and the efficiency of uptake and use of nutrients by plants had slightly less indications (71.4\% of indications). Therefore, the respondents pay attention to the problem of fertilization optimization in the situation of more and more frequent droughts in Poland and in conditions of worsening climatic problems.

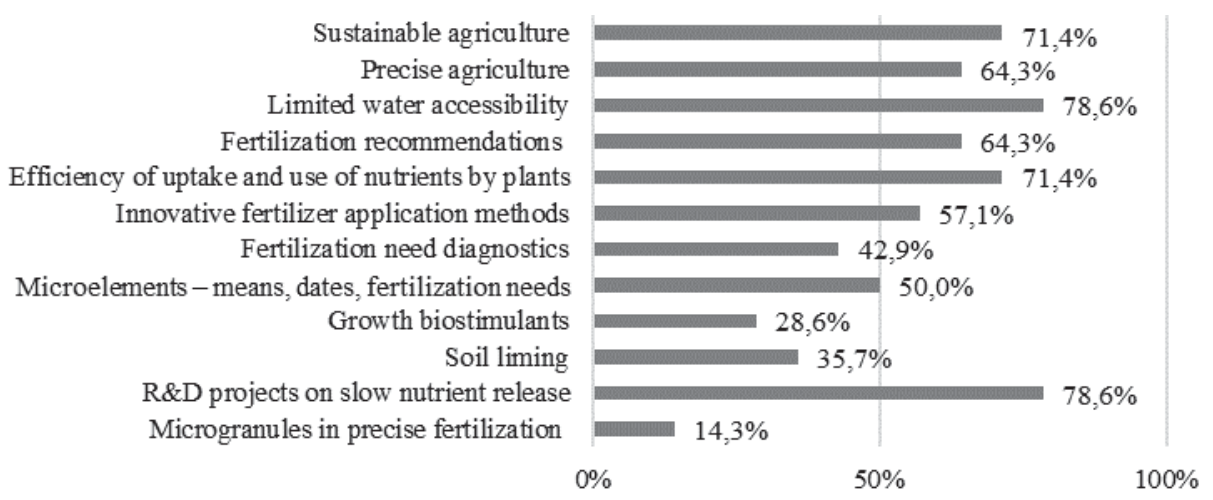

Figure 5. Areas of research and development interests of the Consortium members

Source: Author's own study.

The least attention was paid to the use of microgranules in precise fertilization (14.3\% of indications) and to biostimulants supporting plant growth $(28.6 \%$ of indications). Interestingly, biostimulants are more interesting for producers of means for agricultural production and agricultural entrepreneurs (3 respondents) than representatives of science (1 respondent). Chesbrough and Brunswicker (2018) point out that organizations should use external and internal ideas as well as external and internal market paths to find opportunities for growth. The respondents were asked about the areas of interest of the Consortium Members within the open innovation formula (Figure $6)$.

The respondents would most willingly participate in organizing events aimed at exchanging agricultural knowledge (92.0\% of indications) and creating a platform for communication of partners in implemented projects ( $71.4 \%$ of indications). This proves the huge demand for knowledge exchange between communities, generally speaking, of science, producers and their customers.

The importance of the exchange of knowledge from the Consortium's research carried out in 2015 is confirmed. The Consortium members, on the other hand, are not 
particularly interested in advisory, organizational and financial support, probably leaving it to the project sponsor. What may be interesting is the interest of science and customer representatives in advising on agricultural crops, in the absence of this interest shown by producers. It would seem that this type of business-related service should be used to build better relationships with customers and manage their value. The respondents do not share this opinion.



Figure 6. The areas of interest of Consortium members within the open innovation formula Source: Author's own study.

The importance of the exchange of knowledge from the Consortium's research carried out in 2015 is confirmed. The Consortium members, on the other hand, are not particularly interested in advisory, organizational and financial support, probably leaving it to the project sponsor. What may be interesting is the interest of science and customer representatives in advising on agricultural crops, in the absence of this interest shown by producers. It would seem that this type of business-related service should be used to build better relationships with customers and manage their value. The respondents do not share this opinion.

The respondents were also asked what resources they are able to allocate for joint implementation of research and development projects (Figure 7). The most frequently indicated were access to technology and material resources or research infrastructure (50.0\% of responses). The question did not contain a suggestion whether this sharing should be for a fee or for free, but knowing the realities of the market, it should be presumed that the partners would most willingly provide the mentioned resources for a fee. 




Figure 7. Resources declared by Consortium members for cooperation

Source: Author's own study.

The willingness to share the competences of scientific and research staff, source data from conducted research and project management systems with the Consortium was declared by $43.9 \%$ of respondents. The willingness to transfer the partners' own resources, such as intellectual property or financial resources, is relatively low. Generally speaking, the Consortium members would be willing to take part in the Consortium's projects, most likely using the resources of the sponsor, the Consortium leader, in these areas. They would be less willing to lend their own organizational culture and the competences of employees other than academics and research and development workers $(21.4 \%)$. The relatively high assessment of the importance of organizational culture and reputation for the success of the projects carried out is noticeable, with the Consortium members quite reluctant to share them.

The last research problem concerned the declaration of commitment of the Consortium members in particular phases of the project life cycle (Figure 8). It turned out that the respondents would most willingly take part in initiating projects $(71.4 \%)$ and planning them (64.3\%). Thus, as in the Chesbrough and Brunswicker (2018) studies, who call this stage in their research the 'definition of the project', partners participate and open up more willingly to collaboration.

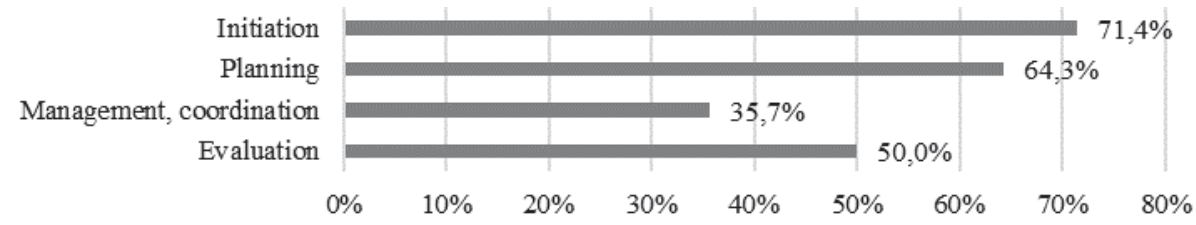

Figure 8. Phases of the project life cycle in which the Consortium members are interested Source: Author's own study.

Less interest is manifested for managing or coordinating projects $(35.7 \%)$. Half of the responses refer to the interest in the evaluation of the project $(50 \%)$, which could prove that the Consortium members are more interested in the results of the work. 


\section{Conclusions}

Summarizing the research, several phenomena can be indicated. On the one hand, the Consortium members appreciate the importance of the competences of employees of scientific centres, business research and development employees and the source data of the conducted research, but they approach the Consortium with a certain reserve. Hence, they most willingly indicate the strategy of limited trust as the most appropriate model of organizational cooperation. This cooperation should be based on the contractual regulations of the parties involved. It is therefore surprising that there is such large support for the model of "soft openness" in the transfer of knowledge between participants. A certain explanation for this phenomenon is the fact that this kind of openness was most often indicated by representatives of research institutions, who are not so strongly associated with the pressure for success of the implementation of research.

The respondents are "hungry" for the exchange of agricultural knowledge, hence they attach importance to the organization of events serving this exchange and building a platform for partner communication under jointly implemented projects. This is good news - the only question is whether the acquired knowledge would serve to increase one's own value or a joint project. The bad news is a reluctance to share this knowledge, for example as part of consulting services.

The respondents most willingly declare the involvement of their "hard" resources, apart from financial resources, underestimating the importance of "soft" skills, such as organizational culture or reputation. They probably underestimate their importance for building the value of their projects. It also seems that since the expectations of the respondents is primarily the involvement of the sponsor's resources (primarily financial resources), they should give consent to its dominant influence in the management of the Consortium. The respondents reluctantly agree to such a solution. They are also reluctant to lead or coordinate the entire project, leaving this role to the leader. Whether it possible to reconcile the apparently contradictory expectations of Consortium members in the pursuit of increasing openness to innovation between all cooperating partners - this is the challenge for the cooperating parties.

\section{References:}

Adegbesani, J. A., \& Higgins, M. J. (2010): The intra-alliance division of value created through collaboration. Strategic Management Journal, 32: 187-211. Available at https://doi.org/10.1002/ smj.872 (accessed Jan 2021).

Adner, R. (2006). Match your innovation strategy to your innovation ecosystem, Harvard Business Review, 84 (4), 98-107. Available at www.hbrreprints.org. (accessed Jan 2021).

Autio, E. \& Thomas, L. (2014). Innovation ecosystems: Implications for innovation management. In M. Dodgson, D. M Gann,. \& N. Phillips, Innovation management: Oxford University Press, 204-288.

Blomqvist, K. \& Levy, J. (2006): Collaboration capability - a focal concept in knowledge creation and collaborative innovation in networks. International Journal of Management Concept and Philosophy, 2 (1), 31-48. Available at https://www.researchgate.net/profile/KirsimarjaBlomqvist/publication/ (accessed Jan 2021). 
Chanal, V., \& Caron-Fasan, M. L. (2010): The difficulties involved in developing business models open to innovation communities: the case of a crowdsourcing platform. Management, 13: 318-340. Available at https://doi.org/10.3917/mana.134.0318 (accessed Jan 2021).

Chesbrough, H., \& Brunswicker, S. (2013): Managing open innovation in large firms. Garwood Center for Corporate Innovation at California University, Berkeley in US \& Fraunhofer Society in Germany. Available at http://www.iot.ntnu.no/innovation/norsi-pims-courses/chesbrough/ (accessed Jan 2021).

Chesbrough, H., Kim, S., \& Agogino, A. (2014): Chez Panisse: Building an open innovation ecosystem. California Management Review, 56 (4): 144-177. Available at https://doi.org/10.1525/cmr.2014.56.4.144 (accessed Jan 2021).

Chesbrough, H., \& Brunswicker, S. (2018): The adoption of open innovation in large firms. Technology Management, 61: 35-45. Available at https://doi.org/10.1080/08956308.2018.1399022 (accessed Jan 2021).

Du, J., Leten, B., \& Vanhaverbeke, W. (2014): Managing open innovation projects with sciencebased and market-based partners. Research Policy, 43(5): 828-840. Available at https://doi.org/10.1016/j.respol.2013.12.008 (accessed Jan 2021).

Fjelstad, Ø. Snow, C. Miles, R. \& Lettl, C. (2012): The architecture of collaboration, Strategic Management Journal, 33 (6), pp.734-750. Available at https://doi.org/10.1002/smj.1968 (accessed Jan 2021).

Gorton, G. B., \& Souleles, N. S. (2007): Special purpose vehicles and securitization. In The risks of financial institutions (pp. 549-602). University of Chicago Press. Available at https://www.nber.org/system/files/working_papers (accessed Jan 2021).

Gulati, R., Nohria N., \& Zahher A. (2000): Strategic networks. Strategic Management Journal, 21 (3): 203-215. Available at https://doi.org/10.1002/(SICI)1097-0266(200003)21:3<203::AIDSMJ102>3.0.CO;2-K (accessed Jan 2021).

Herstatt, C., \& Sander, J. G. (2004): Produktentwicklung mit virtuellen Communities. Wiesbaden, Gabler Verlag. [in Germany]. Available at https://doi.org/10.1007/978-3-322-84540-5 (accessed Jan 2021).

Jackson, D. J. (2011): What is an innovation ecosystem? Arlington, National Science Foundation. Available at https://www.researchgate.net/profile/Deborah-Jackson-7/publication/266414637 (accessed Jan 2021).

Lakhani K. R., von Hippel E. (2004): How open source software works: "free" user-to-user assistance. [in]: Produktentwicklung mit virtuellen Communities. Gabler Verlag, 2004. Available at https://dspace.mit.edu/bitstream/handle/1721.1/70028/von Hippel (accessed Jan 2021).

Laursen, K. \& Salter, A. (2006). Open innovation: The Role of Openness in Explaining Innovation Performance Among U. K. Manufacturing Firms, Strategic Management Journal, 27. Available at doi: https://doi.org/10.1002/smj.507 (accessed Jan 2021).

Olander, H. Hurmelinna-Laukkanen, P. Blomqvist K. \& Ritala, P. (2010). The dynamics of relational and contractual governance mechanisms in knowledge sharing of collaborative R\&D projects, Knowledge and Process Management, 17 (4), 188-204. Available at doi: https://doi.org/10.1002/kpm.356 (accessed Jan 2021).

Pfitzer, M. W., Bockstette, V., \& Stamp, M. (2013): Innovating for shared value, Harvard Business Review, 86: 100-107.

Pokojski, Z. (2018, September): In searching for business model open for innovations on agricultural market - conceptual approach, Proceedings of the 2018 International Scientific Conference 'Economic Sciences for Agribusiness and Rural Economy' No 1, Warsaw, 7-8 June 2018, 237-242, Available at DOI: 10.22630/ESARE.2018.1.33.

Ritala, P., Armila, L., \& Blomqvist, K. (2009): Innovation orchestration capability - defining the organizational and individual level determinants. International Journal of Innovation Management, 13 (4): 569-591. Available at https://doi.org/10.1142/S136391960900242X (accessed Jan 2021). 
Ritala, P., Hurmelinna-Laukkanen, P., \& Nätti, S. (2012): Coordination in innovation-generating business networks - the case of Finnish mobile TV development. Journal of Business \& Industrial Marketing, 27 (4): 324-334. Available at https://doi.org/10.1108/08858621211221698 (accessed Jan 2021).

Teece, D. J. (2007). Explicating dynamic capabilities: the nature and microfoundations of (sustainable) enterprise performance, Strategic Management Journal, 28(13), 1319-1350. Available at doi: https://doi.org/10.1002/smj.640 (accessed Jan 2021).

\section{Partnerstwo w otwartych innowacjach, doświadczenia rynku rolnego. Studium przypadku}

\section{Streszczenie}

Umiejętność budowania i zarządzania partnerstwem w transferze wiedzy jest jedną $\mathrm{z}$ najbardziej pożądanych umiejętności nowoczesnych organizacji. Wiedza jest szeroko rozproszona, tak więc należy pozyskiwać ją z otoczenia a niewykorzystywaną przez organizację udostępniać innym. $\mathrm{W}$ tym celu należy zawiązywać współpracę partnerską z różnymi podmiotami nie tylko z sektora biznesu, ale również z sektora organizacji publicznych i non profit. Można przyjąć, że najbardziej dojrzałym rodzajem partnerstwa jest ekosystem innowacji. Niewielu jeszcze ludzi nauki w Polsce podejmowało temat partnerstwa w zarzadzaniu innowacjami stąd też postanowiono przeprowadzić badania empiryczne wśród konsorcjantów Grupy Azoty Puławy w oparciu o wywiad pogłębiony, częściowo ustrukturyzowany, wsparty analizą kilku wybranych ekosystemów innowacji koncernów chemicznych. Celem badań była ocena zjawiska otwartych innowacji w Grupie wraz z charakterystyką doboru partnerów, strategii współpracy oraz deklarowanych zasobów do wspólnie realizowanych projektów.

Slowa kluczowe: partnerstwo, otwarte innowacje, ekosystem innowacji, zarządzanie innowacjami, transfer wiedzy.

JEL Codes: O320, M21

Information about the author:

Zenon Pokojski PhD (Economics), Assistant Professor, Faculty of Economics Maria Curie- Skłodowska University in Lublin (Uniwersytet Marii Curie Skłodowskiej w Lublinie) 5 Maria Curie-Skłodowska Sq., Lublin, 20-031, Poland e-mail: zenon.pokojski@mail.umcs.pl

ORCID ID: 0000-0001-5870-639 